\title{
Occurrence and Development of a Dorsal Gland in Leaves of Ficus benjamina L. (Weeping Fig) Cultivars
}

\author{
Svoboda V. Pennisi ${ }^{1}$ and Dennis B. McConnell ${ }^{2}$ \\ Department of Environmental Horticulture, University of Florida, Gainesville, \\ FL 32611 \\ Richard W. Henley ${ }^{2}$ \\ Central Florida REC Apopka, 2807 Binion Road, Apopka, FL 32703-8504
}

Additional index words. wax gland, phenolic gland, glandular epithelium, extrafloral nectaries, morphology

\begin{abstract}
Detailed anatomical observations of the dorsal gland and its development in Ficus benjamina L. (Weeping Fig) leaves are reported. The dark spot on the abaxial surface of Ficus benjamina leaves is a normal morphological feature of the species. It is a highly specialized modified epidermal layer. An investigation of six commercially available cultivars revealed all possessed a glandular dorsal epidermis but not all developed a pigmented gland. The variability in gland thickness suggests that differences exist between cultivars. Based on histochemical tests, we propose that the term "phenolic gland" be substituted for the term "wax gland" found in the literature, as all tests indicated the presence of polyphenols in the glandular epithelium of $F$. benjamina leaves.
\end{abstract}

Foliage plant production represents an important agricultural industry in the United States, with a net wholesale value of $\$ 432.5$ million in 1996 (U.S. Dept. of Agriculture, 1997). Members of the genus Ficus (Moraceae) represent an important component of the foliage plant product mix and rank third with $6.5 \%$ of total sales in Florida (McConnell et al., 1989). Currently, Florida growers advertise 14 Ficus species, among which $F$. benjamina is represented by 17 cultivars (Florida Nurserymen and Growers Association, 1997). Variously sized (0.3-4 m) Ficus benjamina plants are an integral part of many modern interior landscapes. Growers and interiorscape managers have often observed a suspected disease or insect problem on $F$. benjamina - the occurrence of a single dark oval spot on the abaxial surface of the lamina at the blade/petiole junction. Periodically, $F$. benjamina leaf samples are submitted to Univ. of Florida personnel for diagnosis of this problem after pesticide applications have failed to eliminate it.

Renner (1907) illustrated wax glands, or extrafloral nectaries, in nine species of Ficus: $F$. bengalensis L., F. religiosa L., F. glomerata L., F. canai L., F. urophylla Wallich, F. cunia Buch.-Ham. Ex Sm, F. roxburghii Lour., $F$. hispida $\mathrm{L}$., and $F$. diversifolia Blume. Lersten

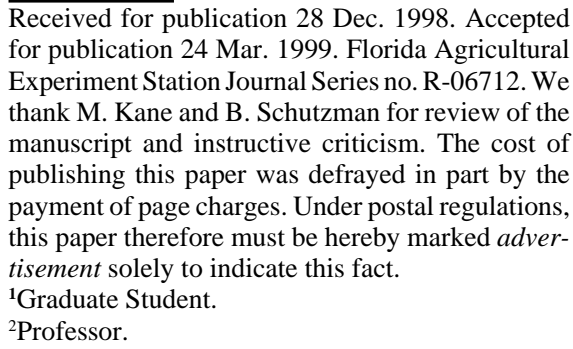
for publication 24 Mar. 1999. Florida Agricultural Experiment Station Journal Series no. R-06712. We thank M. Kane and B. Schutzman for review of the manuscript and instructive criticism. The cost of publishing this paper was defrayed in part by the payment of page charges. Under postal regulations, this paper therefore must be hereby marked advertisement solely to indicate this fact.

${ }^{1}$ Graduate Student.

${ }^{2}$ Professor.

and Petersen (1974) described red pigment spots on the abaxial surface of $F$. diversifolia leaves. The spots consisted of palisade-like epidermal cells, filled with an unknown pigment. The pigmented structures were not involved in any secretory activity. More detailed anatomical observations on the dorsal gland of $F$. benjamina were reported by Neves and Filho (1986). Although the term "wax gland" has been repeatedly used in the surveyed literature, we know of no reports on the chemical nature of the substance(s) contained in or exuded from the gland. Condit (1969) stated that the function of the "wax glands" in Ficus species was speculative.

This study was undertaken to clarify the development and characteristics of the dark leaf spots in $F$. benjamina. Six commercially available cultivars of $F$. benjamina were subjected to detailed anatomical analysis to determine commonalities and differences in development and structure of the abaxial leaf spot.

\section{Materials and Methods}

The following six cultivars of $F$. benjamina were obtained from the Central Florida Research andEducation Center in Apopka: 'Christine', 'Citation', 'Kiki', 'Wintergreen', 'Dwarf Nikita', and 'Starlite'. The last two cultivars have variegated foliage. All plants were $\approx 0.3$ $\mathrm{m}$ in height. In addition, a $F$. benjamina specimen grown in the Environmental Horticulture Conservatory at the Univ. of Florida at Gainesville was sampled. The latter was $\approx 2.5$ $\mathrm{m}$ in height and displayed prominent darkcolored spots on the abaxial leaf base. Leaf samples of the conservatory specimen included developing and mature leaves that were $>1$ year old. Leaf samples from the other six cultivars included mature leaves only. Leaf (lamina and petiole) and internode lengths presented are ranges obtained from 10 measurements. For anatomical observations, plant tissues were fixed in formalin-acetic acidethyl alcohol (FAA), dehydrated in a graded tertiary butyl alcohol series and placed in tissue embedding medium (Paraplast X-Tra at 50 to $54^{\circ} \mathrm{C}$ ). Transverse sections of the leaf pieces were cut manually at $10 \mu \mathrm{m}$ with a rotary microtome. Slides used for general anatomical observations were stained in $0.25 \%$ aqueous Toluidine Blue O (Sakai, 1973). Detailed cellular measurements were made directly with an ocular micrometer. Fresh leaf tissue sections were tested for polyphenols following procedures outlined by Reeve (1951). Positive reaction to polyphenols is indicated by the formation of colored compounds (phlobaphenes) upon reaction with sodium nitrite followed by sodium hydroxide. Fresh leaf tissue sections were also tested for the presence of magnesium in the latex by treating tissue microsections with Titan Yellow followed by sodium hydroxide, according to a procedure outlined by Jensen (1972). Specimens were viewed with a Nikon Optiphot-Pol research microscope (Nikon Nippon Kogaku K.K., Tokyo) and photographed with an automatic Nikon UFX-II (Nikon Nippon Kogaku K.K.) camera attachment.

\section{Results and Discussion}

General observations. When present, all dark brown spots were located on the abaxial leaf surface at the junction of the petiole and lamina (Fig. 1A), and these spots were 1 to 6 $\mathrm{mm}$ long and 1 to $3 \mathrm{~mm}$ wide (Fig. 1B). Recently matured leaves often had a white exudate instead of a dark spot at the petiole/ lamina junction (Fig. 1C). We observed that plants located near the greenhouse fan had a higher incidence of white exudation, indicating that physical disturbance of the leaves by air currents induced leakage of latex in the glandular region. Upon exposure to air, the latex rapidly crystallized, forming a white exudate. Histochemical tests using Titan Yellow showed positive reaction for magnesium in the white exudate. Magnesium salts have been previously reported in the latex of Moraceae species (Metcalfe and Chalk, 1983).

The dark spot on sectioned mature leaves consisted of palisade epithelium made up of densely stained, elongated cells with thick walls (Fig. $1 \mathrm{D}$ and E). The cell lumen was filled with a granular heterogeneous substance that resembled tannin inclusions. Colorimetric tests using a nitrous acid derivative (Reeve, 1951) showed a positive reaction for polyphenols. The glandular cells varied from elongate-rectangular, elongate-triangular, and cuboidal to isodiametric. Anticlinal divisions in the epidermal cells had produced a stratified epithelium in some glands. The cuticle covering the gland was thickened. No vascular continuity with the midrib was evident. A subepidermal layer of isodiametric cells with similar contents was found underneath the elongated epidermal cells (Fig. 1E). These 

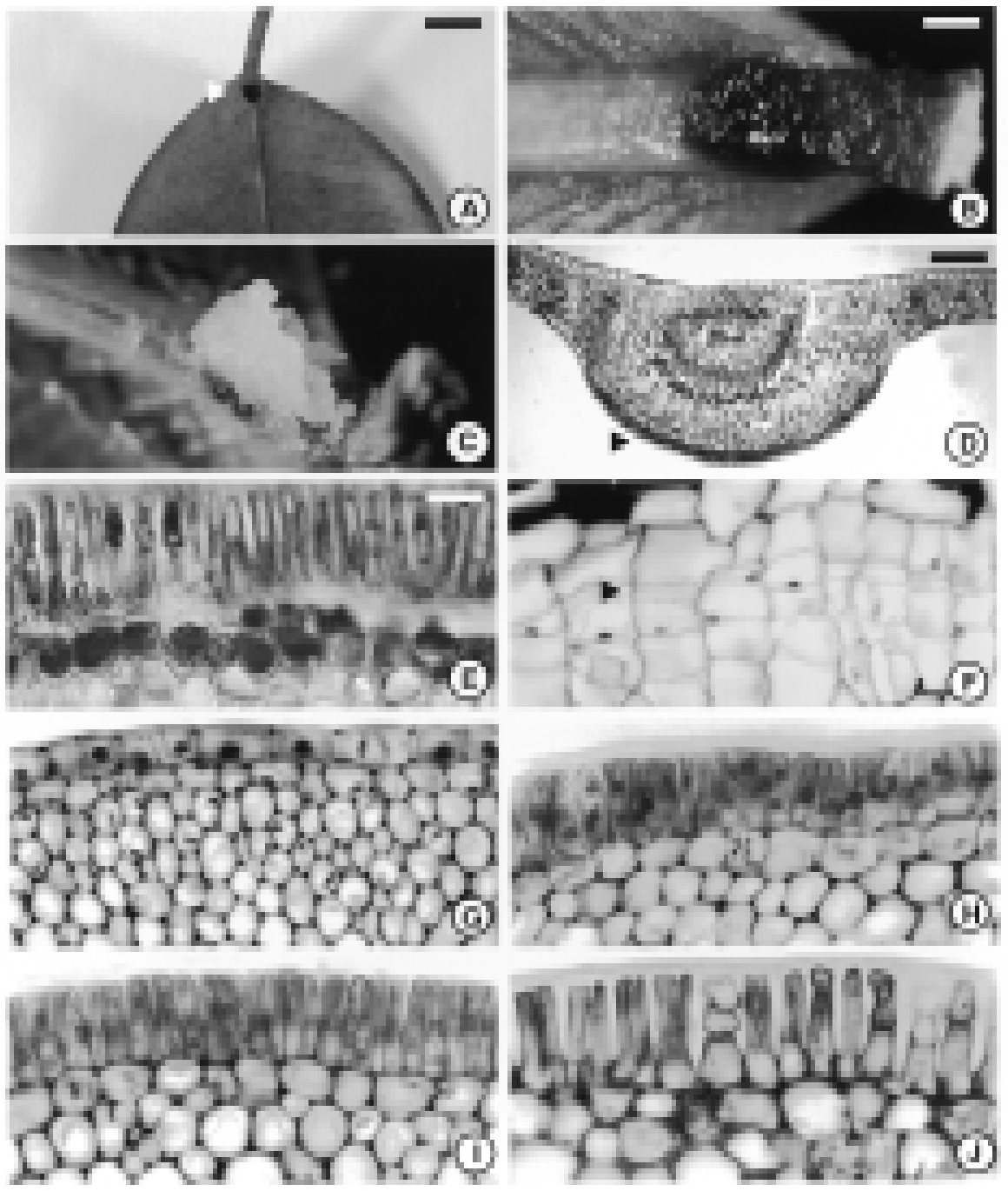

Fig. 1. Dorsal leaf gland in Ficus benjamina leaves. (A) Abaxial leaf side. The arrowhead points at the dark oval spot. Bar $=2 \mathrm{~cm}$. (B-C) Dark spot and white exudate in the glandular region, respectively. Bar = $10 \mathrm{~mm}$. (D) Transverse section through the midrib showing the crescent-shaped glandular epithelium (arrowhead). Bar $=0.5 \mathrm{~mm}$. (E) Transverse section through the glandular and subglandular regions. (F) Meristematic-like cells of the subglandular region (arrowhead). (G-J) Stages in the gland's development. (G) Leaf is $10 \%$ of mature size. (H) Leaf is $40 \%$ of mature size. (I) Leaf is $60 \%$ of mature size. (J) Leaf is $100 \%$ of mature size. In $\mathbf{E}-\mathbf{J}$, bar $=20 \mu \mathrm{m}$.

cells also tested positive for polyphenols. When the gland was very dark and prominent, a double layer of thin-walled meristematic-like cells developed, contributing to the gland's thickness (Fig. 1F). Those cells later became filled with tannin-like inclusions.

Gland development. In leaves $\approx 10 \%$ of mature size, the abaxial glandular cells appeared to be indistinct from the surrounding epidermal cells (Fig. 1G). When the leaf reached $\approx 20 \%$ of its final size, changes in cell orientation were detected. Previously, the long cell axis had been parallel to the leaf surface, but was now perpendicular. Further cell divisions anticlinal to the surface continued as the leaf reached $30 \%$ to $40 \%$ of mature size (Fig. $1 \mathrm{H})$. A modified epithelium was present as the leaf neared $50 \%$ of final size and was clearly defined at $60 \%$ of its final size (Fig. 1I). Cell divisions by that time were periclinal, anticlinal, and oblique to the leaf surface. Further cell divisions, accompanied by cell elongation of but white exudate was commonly found (Fig. $2 \mathrm{C}$ ). The epithelium was stratified, 45 to 50 $\mu \mathrm{m}$ thick, and contained large intercellular spaces (Fig. 2D).

'Kiki' is a dwarf form with diminutive leaves (4.5-6.5 cm long), 1- to $1.5-\mathrm{cm}$-long internodes, and upright habit. The gland ranged from small $(1 \mathrm{~mm})$ to medium $(2 \mathrm{~mm})$ (Fig. $2 \mathrm{E})$. The epithelium was a single layer, 25 to $30 \mu \mathrm{m}$ thick (Fig. 2F). 'Wintergreen' was characterized by 7- to 8-cm-long leaves, 2.5to $3-\mathrm{cm}$-long internodes, and spreading habit. The gland could not be detected externally and white exudate was present only in a few leaves (Fig. 2G). The epithelium was a single layer, 25 to $30 \mu \mathrm{m}$ thick (Fig. 2H). 'Dwarf Nikita' is a dwarf form with small variegated leaves (3$5 \mathrm{~cm}$ long), 2- to 2.5 -cm-long internodes, and upright habit. The gland was large, $\approx 3$ to $4 \mathrm{~mm}$ long (Fig. 2I). The epithelium was a single layer, 18 to $20 \mu \mathrm{m}$ thick (Fig. 2J). Heavy deposition of phenolic compounds was evident in the glandular cells. 'Starlite' was characterized by 6 - to $7-\mathrm{cm}$-long variegated leaves, $2-$ to $2.5-\mathrm{cm}-$ long internodes, and spreading habit. Glands ranged from medium $(2 \mathrm{~mm}$ long) to large (3 mm long) (Fig. 2K). White exudate was commonly present. The epithelium was nonstratified, 20 to $25 \mu \mathrm{m}$ thick (Fig. 2L). Heavy deposition of phenolic compounds was evident in the glandular and subglandular regions.

In conclusion, the dark spot on the underside of Ficus benjamina leaves is a normal morphological feature of the species. It is a highly specialized modified epidermal layer. The variability in gland thickness suggests that differences exist between cultivars. Although the gland was present in every cultivar examined, not all developed dark pigmentation. A positive correlation existed between leaf age and the appearance of a dark gland color. The presence of a white exudate consisting of crystallized latex supports our hypothesis that physical disturbances accentuate exudation around glandular cells. Note that the latex exudate originated from areas surrounding the gland and not from the glandular cells themselves. Secretion of the white exudate may be accomplished by a minute rupturing of the cuticular layer (Martin and Juniper, 1970). The presence of white exudate in close proximity to the gland should not be confused with the excretion of latex directly from the glandular cells. Instead, it may be an unrelated plant activity. Although latex could be excreted directly from the gland, it probably originates from deeper, nonglandular tissues. The dark coloration of the gland is probably caused by the polyphenols, which form polymeric dark red or brown compounds (phlobaphenes) upon exposure to air (Reeve, 1951). This would explain the positive correlation between leaf age and appearance of a dark color. The function of the gland is presently unknown. However, given the presence of polyphenolic compounds, its role may be protective. Histochemical tests of the glandular region have not been previously reported. Based on these tests, we propose that the term "phenolic gland" be substituted for the term "wax gland." 

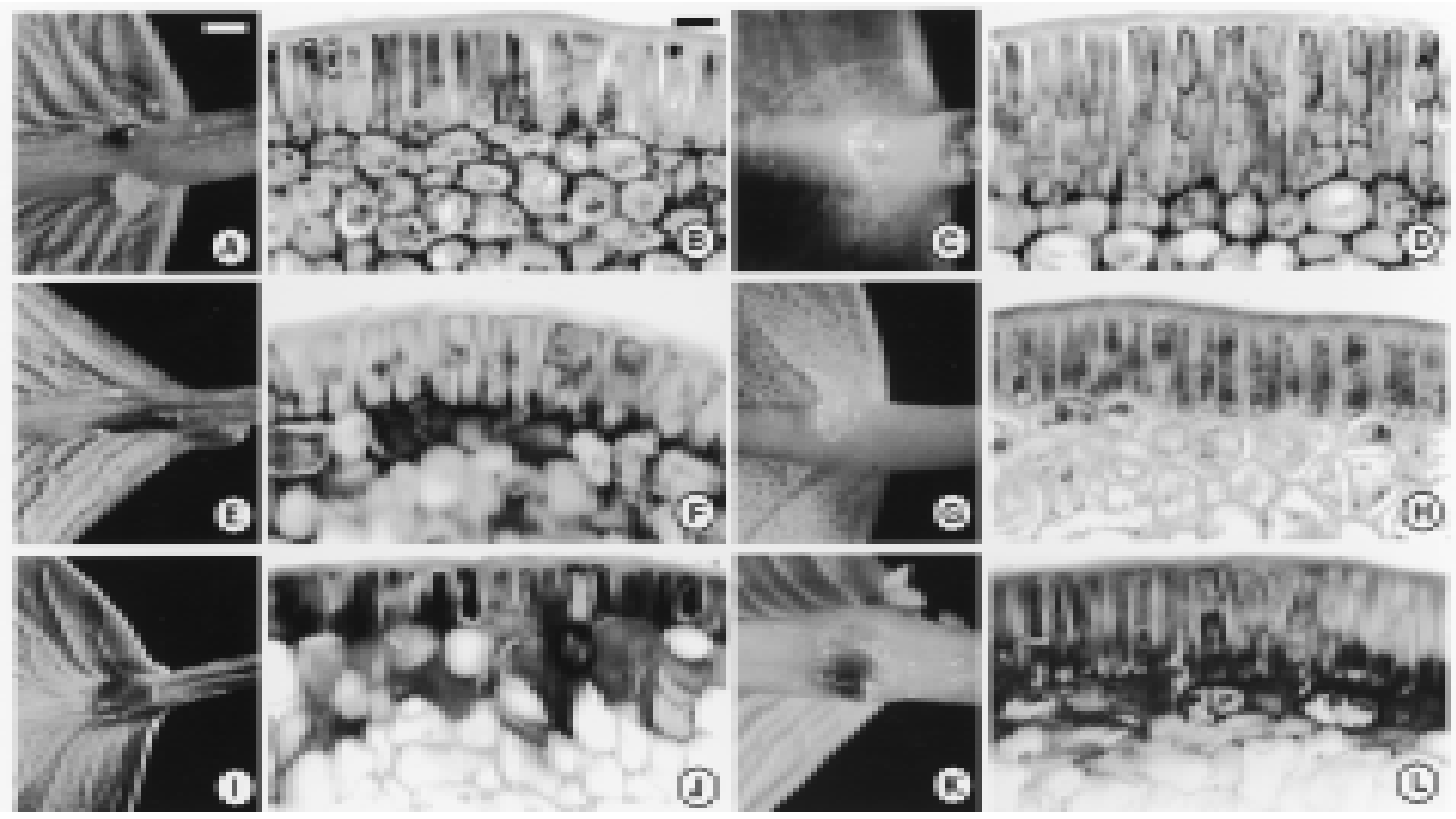

Fig. 2. Dorsal leaf glands in six cultivars of Ficus benjamina. (A, C, E, G, I, and K) Low magnification views of 'Christine', 'Citation', 'Kiki', 'Wintergreen', 'Dwarf Nikita', and 'Starlite', respectively. (B, D, F, H, J, and L) Transverse sections through the glandular epithelium of 'Christine', 'Citation', 'Kiki', 'Wintergreen', 'Dwarf Nikita', and 'Starlite', respectively. In $\mathbf{A}, \mathbf{C}, \mathbf{E}, \mathbf{G}, \mathbf{I}$, and $\mathbf{K}$, bar $=10 \mathrm{~mm}$. In $\mathbf{B}, \mathbf{D}, \mathbf{F}, \mathbf{H}, \mathbf{J}$, and $\mathbf{L}$, bar $=10 \mu \mathrm{m}$.

\section{Literature Cited}

Condit, I.J. 1969. Vegetative and botanical characters, p. 26-35. In: Ficus: The exotic species. Univ. of California, Div. Agr. Sci.

Florida Nurserymen and Growers Association. 1997. Plant sources, p. 104-106. In: FNGA Locator. Florida Nurserymen and Growers Assn., Orlando.

Jensen, W.A. 1972. Minerals, p. 284. In: Botanical histochemistry. W.H. Freeman, San Francisco and London.

Lersten, N.R. and W.H. Petersen. 1974. Anatomy of hydathodes and pigment discs in leaves of $F$. diversifolia (Moraceae). Bot. J. Linn. Soc. 68:109-113.

Martin, J.T. and B.E. Juniper. 1970. The anatomy and morphology of cuticles and barks, p. 71119. In: The cuticles of plants, St. Martin's Press, New York.

McConnell, D.B., R.W. Henley, and C.B. Kelly. 1989. Commercial foliage plants: Twenty years of change. Proc. Florida State Hort. Soc. 102:297-303.

Metcalfe, C.R. and L. Chalk. 1983. Secretory structures: Cells, cavities and canals, p. 70-81. In: Anatomy of the dicotyledons. Vol II. Wood structure and conclusions of the general intro- duction. Clarendon Press, Oxford, U.K.

Neves, L.J. and L.E. Filho. 1986. Anatomia foliar de Ficus benjamina L. Bradea 37:295-304.

Reeve, R.M. 1951. Histochemical tests for polyphenols in plant tissues. Stain Technol. 26:91-96.

Renner, V.O. 1907. Uber Wachsdrüsen auf den Blattern und Zweigen von Ficus. Flora 7:24-37.

Sakai, W.S. 1973. Simple method for differential staining of paraffin embedded plant material using Toluidine Blue-O. Stain Technol. 48:247249.

U.S. Dept. of Agriculture. 1997. Floriculture crops 1997 summary. U.S. Dept. Agr., Washington, D.C. 